\title{
How Does Board Diversity Affect The Financial Performance Of Commercial Banks In Indonesia? An Inquiry
}

\author{
Maria Jacinta Arquisola, Kezia Shella and Erny Hutabarat \\ Prsiden University \\ Email:mjarquisola@president.ac.id
}

\begin{abstract}
This study analyzes board diversity and its effect on financial performance, as measured by age, gender, and nationality of board members using a sample of nine (9) commercial banks in Cikarang, West Java, Indonesia. The study uses multiple linear regression analysis. The results show that age and nationality have significant effect, while gender has insignificant effect on financial performance. However, simultaneously all of the independent variables significantly affect the Return on Asset, with the coefficient determinant in this research is $20.8 \%$.
\end{abstract}

Key words: Board diversity, firm performance, age, gender, nationality.

\section{INTRODUCTION}

The purpose of this study is to analyze the effects of board member diversity on the financial performance of commercial banks in West Java, Indonesia. As an emerging capital market, Indonesia is a big draw for foreign investments where, by the end of 2015, the Indonesia Stock Exchange (IDX) recorded foreign investors had 67.1 percent of the shares total value traded on the IDX. This signals that it is most likely foreigners would like to participate in the management of Indonesian companies, and might themselves be interested in having representation and position in boards.

Recent research on firm performance has narrowed focus on the significance of board diversity as creating value to the financial health and stability of firms. Governments have also expressed interest in the role of board diversity to financial performance A study of top 500 Australian firms in 2011 shows how a diverse membership of boards, reflecting Australia's multi-cultural society, has been instrumental in more positive financial performance for these firms (Kusumastuti, 2007).

Globally, diversity has become an important indicator in countries that have set the rules for board composition. For example, Norway has implemented gender quota in order to improve equal opportunities (Smith and Verner, 2006). In Malaysia also imposed a 30 percent quota for women on to become board members (The Economist, 2014). Except for the study by Darmadi (2013) on board diversity and firm performance using IDX data, research and awareness on the significance of board diversity to firm performance is dearth in Indonesia. One of the reasons being that Indonesia does not have guidelines for board diversity under the Indonesia Stock Exchange code, resulting in lack of institutional support, especially for better gender representation in boards.

This makes this study important in contributing to a greater understanding of board diversity, especially in the issue of gender, in an Indonesian context. Currently, there is 
heightened awareness of promoting gender equality, and creating better gender awareness has been the focus of many feminist-based studies over the past decades (OeyGardiner, 2002; Robinson, 2004, 2009; Robinson \& Bessell, 2002; Surbakti, 2002). This effort is shown by the creation of agencies and institutions supporting women's equality, rights, protection, and welfare. This interest and attention on gender representation in many facets of Indonesian society is made evident by increasing awareness on the role of women in business and industry. However, the effects of gender on the financial performance of the banking industry is yet to be explored.

Based on the rationale above, there is an urgent need for greater diversity, in terms of gender, nationality, and age in boards in the Indonesian commercial banking sector. According to Indonesian Law, a corporation should have a Board of Director or BOD (Dewan Direksi) and Board of Commissioners or BOC (Dewan Komisaris). The members of the BOC and BOD are selected during the shareholders' general meeting. Under Indonesian regulations, a firm should possess independent commissioners of at least of $30 \%$ of total number of Board of Commissioner members and the requirement is to have at least one unaffiliated members of the Board of Director. Yet there is no requirement for what should be the composition of the board, nor is it emphasized that a board must have the right composition of gender, age, and nationality.

\section{THEORETICAL FRAMEWORK}

Board Diversity and Financial Performance. Board diversity is defined as variety in the composition of the board. This is divided into observable and non-observable diversity (Kang et al., 2007). Diversity between members of top level could bring many effects to the organization activities, such as communication problems and interpersonal conflicts (Cox, 1991). Board diversity is essential to the establishment of new ideas and to maximize differences in cultures, ages, and genders. Additionally, diversity may into an advantage when it is well managed (Hilb, 2012). However, diversity could be an advantage also as well as more variance in decision making, more innovation and creativity (Robinson and Dechant, 1997; Cox and Blake, 1991).

Financial performance is related to the firm's ability to generate net income or income. It is often used as a general measurement of job results to determine how good a company is in doing its business activities. It can also be used to compare between companies and an industry. There is a wide range of financial performance measures, for example, Return on Assets, Return on Equity, and Return on Investments, among others (Orlitzky, Schmidt, and Rynes, 2003).

Studies on the advantages of gender diversity on boards is well documented by many studies. For example, work by Tu, Loi and Yen (2015) on ASEAN banks show that when there are more women on boards, firm performance, measured through the ROA goes up tremendously. The same results were also arrived at by studies done on Dieleman, Meijun, and Ibrahim (2014). However in contrast, studies by Cilic (2015) in Turkey shows that there is in fact a negative relationship whereby gender and nationality do not create the desired positive impact. Furthermore, study by Darmadi (2013) in 
Indonesian companies also shows that none of the proportions of nationality, gender, and age have positive significant effects on company performance.

In this research, the researcher used Return on Assets (ROA) as a tool to measure commercial banks financial performance. Rist and Pizzica (2015) emphasized that, as a measure of financial performance, return on assets shows how profitable assets are in generating revenue. Return on Assets (ROA) measures how efficient a firm uses the firm assets to generate net income. To be specific, ROA ratio is a proxy that a firm's assets are productive and well managed or not. In other words, the ROA explains how much capital capabilities invested into assets turn into net income. The ROA as a measure of financial performance has been applied in previous studies (Adams et al. (2009; Haniffa and Hudaib, 2006; Adams and Ferreira, 2009).

Age. Age is defined as a proxy for the level of risk-taking and experience attitude (Hermann and Datta, (2005). Young directors tend to undertake critical decisions which scholars argue would create higher growth for firms, compared to those firms with older directors on board. Barker and Mueller (2002) identified that older managers tend not to be risky, while a young director tends to have higher ability to have new ideas and less interest in career level (Cheng et al., 2010). On the other hand, some researchers provide proof that older directors have an impact on financial performance as they have more experience and practices that could be skill- based competencies, like those found in the a study in China. (Cheng et al., 2010). Other researches show the relationship between age of board members with a company's financial performance (Kilduff, 2000; Ararat et al, 2010), while in Europe, some studies show that age has no significant effect in the financial performance of Nordic and Swedish banks (Randoy et al; Eklund, 2009). Similarly, Kusumastuti et al. (2007) found there is no evidence of financial performance and age of board of directors in a study of Indonesian banks.

Gender. Prevailing gender literature argue that there are many constraints deterring female board members from enacting their roles or advancing in their leading roles. Studies have cited social, cultural and historical barriers, for example, gendered roles favouring men, gender discrimination, a male-dominated education system, and reluctance to take up higher posts because they believed that men better deserved to be at the top (Anderson \& Kilduff, 2009; Coleman, 2007, 2010; Cubillo \& Brown, 2003; Ely, Ibarra, \& Kolb, 2011; Kaufman \& Grace, 2011; Killingsworth, Cabezas, Kensler, \& Brooks, 2010; Oplatka, 2006). Eagly and Karau (2002) argued, similarly, that women are subjected to systemic prejudice, the popular concept of the "glass ceiling" because they are perceived less favourably than men as potential occupants of leadership positions.

Table 1 below shows that among emerging economies in Asia, including Indonesia, there is similarly low proportion of gender representation in boards.

On the other hand, studies show that having sufficient gender representation on boards enable better handling of organizational conflict as women are known to be capable of easing situations of misinformation and conflict (Mosakowski and Earley, 2000), where they place more emphasis on harmony and trust (Hurst, 1989). Campbell and Minguez-Vera (2008) also noted studies showing that having a satisfactory gender representation in boards can bring about more innovation and creativity. 
Table 1. Proportion in each region split by the number of women on board

\begin{tabular}{lccccc}
\hline \% in each region & 0 & 1 & 2 & $\geq 3$ & Total \\
\hline North America & 15.8 & 32.4 & 33.1 & 18.7 & 100 \\
Europe & 16.3 & 27.4 & 28.7 & 27.6 & 100 \\
EMEA & 34.7 & 26.0 & 20.0 & 19.3 & 100 \\
Latin America & 60.8 & 28.0 & 8.8 & 2.4 & 100 \\
Developed Asia & 68.0 & 19.8 & 9.4 & 2.8 & 100 \\
Emerging Asia & 72.1 & 15.8 & 7.3 & 4.8 & 100 \\
\hline
\end{tabular}

Source: Credit Issue, 2015

Women are defined 'tough' as they have to deal with many challenges to be on board (Krishnan and Park, 2005). Yet on the other hand, some researchers provide evidence that women may enlarge the possibility of conflicts (Joshi, et al., 2006; Richard, 2004), slow down decision-making (Hambrick, 1996), and according to (Gianakoplos and Benasek, 1998) gender lead to differences in responding to risks.

Links between gender and company performance have been established by contemporary research, and as Smith et al., (2005) study indicates, gender does have an effect on company performance, as evidenced in Danish firms. Yet Adams and Ferreira (2009) study shows the contrary, where the existence of women existence on board has had no direct effect on company performance (see also Bar, 2008 study on American firms). In Indonesia, using a sample of 42 Indonesian companies of manufacturing, the study by Kusumastuti et al., (2007) indicated that gender in board membership has in fact no effect on company financial performance.

Nationality. Nationality can be defined as a devotion to one's nation or a policy of national independence (Simpson and Weiner, 1991). The appearance of foreign nationals on board are expected to bring advantages to the company (Oxelheim and Randoy, 2003). On the other hand, (Lehman and Dufrene, 2008) indicated there is evidence that nationality and culture on board members could enlarge the possibility of cross-cultural communication problem and interpersonal conflicts.

Evidence between nationality and financial performance generally comes from developed economies. For example, the study by Ruigrok and Kaczmarek (2008) shows that the nationality of board members has been shown to affect the financial performance of banks in the UK, Switzerland, and Netherlands. Similarly, Korean firms have also benefited from the positive impact on financial performance of having foreign directors on their boards (Choi and Hasan, 2005). In the context of developing countries itself, higher representation of foreign nationalities on the boards lead to higher return on asset 
in the Turkish firms (Ararat et al, 2010). Conversely, it is not altogether true that the proportion of foreign nationals create such effects on financial performance (Kilduff et al., 2000; Rose, 2007).

Return on Assets. In this study, the ROA is used as the financial ratio to analyze the commercial banks' financial performance. The ROA is a financial ratio that helps analyze a bank's financial health, and is useful tool for investors and creditors to use. The creditor may use those ratios to estimate the rate of return from the bank. The formula for Return on Asset (ROA) is follows:

$$
\text { ROA }=\frac{\text { Income before Tax }}{\text { Average of Total Asset }} \times 100 \%
$$

The ROA provides the image of bank profitability and productivity (Reeve, Warren, and Duchac, 2007). It is computed by dividing income before tax with average total assets (Siamat, 2005). According to Lestari and Sugiharto (2007) and Bank Indonesia Decree No. 7/69/PSHM/ Public Relation, an ROA above 2\% places the bank in a good category of financial robustness. For purposes of this research, the indicator 'good category' (ROA above $2 \%$ ) was used as a criteria for choosing the commercial banks that were included in this research. Below is the theoretical framework analyzing the effect of board diversity and commercial banks' financial performance using the ROA as the dependent variable.

\section{Theoretical Framework: Board Diversity and Financial Performance}

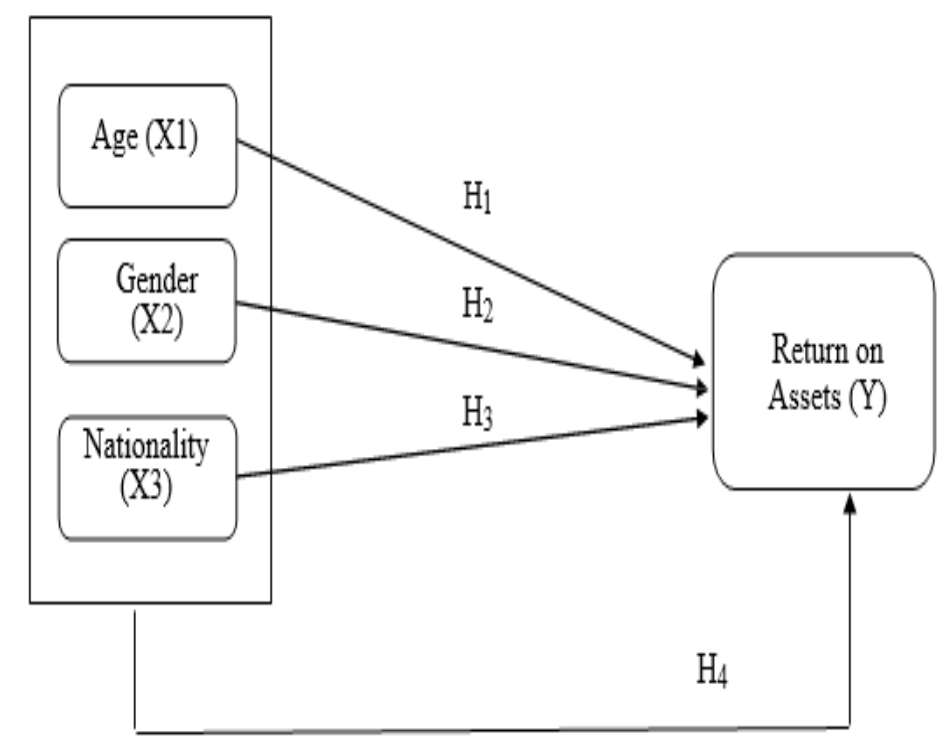

Figure 1. Research Theoretical Framework Source: Framework adopted from various research 
The independent variables of this research are age, gender, and nationality. Morck et al. (1989) indicate that a board members like CEO, Chairman or President must not be aged more than 60 years old. For Indonesia's case, because of differences in life expectancy (see Social Affair and United Nations Department of Economic, 2007) and age of retirement, the researcher chose 50 years old as the threshold age (as of 31 December 2015) for board members in the selection of banks participating in the study. Gender is measured by the number of female board members, while nationality is measured by the number of foreign director on board. Below is the summary of indicators and sources of each variable.

Table 2. Variable Criteria

\begin{tabular}{lll}
\hline Variables & Indicators & Sources \\
\hline Age & No more than 50 years & Morck et al. (1989) \\
& & \\
Gender & Women & Kusumastuti (2010) \\
Nationality & Foreigners & Oxelheim and Randoy et al. (2003) \\
Return on Assets & Above $>2 \%$ & Lestari and Sugiharto (2007) \\
\hline
\end{tabular}

\section{RESEARCH APPROACH}

Data Collection and Sampling. This is a quantitative research using secondary data. In this study, the researcher use nine (9) commercial banks in Cikarang, Bekasi, Indonesia as a sample, from a total number of 35 pre-selected commercial banks in the Cikarang, Bekasi area. The nine (9) commercial banks were selected using purposive sampling ('good category banks with ROA above $2 \%$ ). Purposive sampling was used because it was appropriate for this type of research where generalization was not the purpose of the study (Neuman, 2012) and also the purposive selection of data resources relates to the idea that it is not important how much data were gathered or from how many sources (Polkinghorne, 2006, p.140)

The financial data required for this study (Return on Asset) was obtained from the 9 commercial banks Annual Report of 2015. The researchers obtained age, gender, and nationality mainly from the banks' annual reports which are publicly available documents that can be downloaded from IDX or the banks' website. However, since the data was not always available in the annual reports, the researcher obtained the data from other reliable sources like the firm's legal document (e.g. the websites of Financial Times and Reuters and documents of shareholders general meeting).

\section{METHOD}

Result of Normality Test. Normality test was used to prior to the multiple regression analysis to determine normal or almost normal distribution (Priyatno, 2008). In this study, the researcher used P-Plot Test which shows below that the residual data is normal. 


\section{Normal P-P Plot of Regression Standardized Residual}

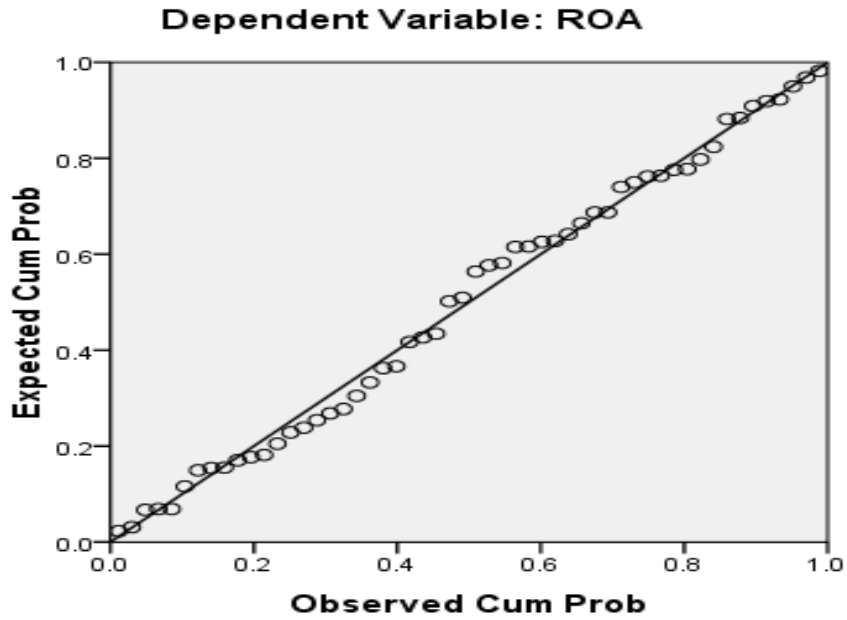

Figure 2. Normality P-Plot Test Result

Result of Multi-Collinearity Test. In this study, the multicollinearity was analyzed using the tolerance value and variance inflation factor (VIF). When the tolerance value is more than $0.10(>0.10)$ or VIF is less than $10(<10)$, it can be concluded there is no multicollinearity between the independent variables in the regression.

Table 3. Multicollinearity Test Result

\begin{tabular}{|c|c|c|c|c|c|c|c|c|}
\hline \multicolumn{9}{|c|}{ Coefficients $^{\mathrm{a}}$} \\
\hline \multirow[b]{2}{*}{ Model } & & \multicolumn{2}{|c|}{$\begin{array}{c}\text { Unstandardized } \\
\text { Coefficients }\end{array}$} & \multirow{2}{*}{$\begin{array}{c}\text { Standardized } \\
\text { Coefficients } \\
\text { Beta }\end{array}$} & \multirow[b]{2}{*}{$\mathrm{t}$} & \multirow[b]{2}{*}{ Sig. } & \multicolumn{2}{|c|}{$\begin{array}{c}\text { Collinearity } \\
\text { Statistics }\end{array}$} \\
\hline & & B & Std. Error & & & & Tolerance & VIF \\
\hline 1 & (Constant) & 9.174 & 2.361 & & 3.886 & .000 & & \\
\hline & AGE & -.667 & .277 & -.299 & -2.407 & .020 & .971 & 1.030 \\
\hline & GENDER & -.298 & .408 & -.091 & -.729 & .469 & .955 & 1.047 \\
\hline & NATIONALITY & -1.445 & .406 & -.442 & -3.559 & .001 & .968 & 1.033 \\
\hline
\end{tabular}

a. Dependent Variable: ROA

From the result shown, all of the independent variables have the value of tolerance that more than 0.10 and VIF less than 10. Age $\left(X_{1}\right)$ tolerance value is $0.971(>0.10)$ and VIF $1.030(<10)$. Gender $\left(\mathrm{X}_{2}\right)$ tolerance value is $0.955(>0.10)$ and VIF $1.047(<10)$. Nationality $\left(\mathrm{X}_{3}\right)$ tolerance value is $0.968(>0.10)$ and VIF $1.033(<10)$. Therefore, all of the independent variables in this study are free from multicollinearity.

Result of F-Test. The F-test is aimed to test the influence of all independent variable toward dependent variable simultaneously or not. Degree of confidence is $5 \%$. If the 
significant test is greater than 0.05 , the independent variable does not significantly affect the dependent variable at all. On the other hand, of the significant test is less than 0.05 , it can be concluded that at least one of the independent variable significantly affect the dependent variable. From the result shown, F statistic value is 5.635 with significance ( $p$ value) of 0.002 . The $p$ value shows a result which lower than 0.05 . It can be concluded that independent variable simultaneously contributes significant effect on dependent variable or at least one of the independent variables influences the dependent variable.

Table 4. F-Test Result of all independents variable

\begin{tabular}{|c|c|c|c|c|c|c|}
\hline \multicolumn{7}{|c|}{ ANOVA $^{b}$} \\
\hline \multicolumn{2}{|l|}{ Model } & $\begin{array}{l}\text { Sum of } \\
\text { Squares }\end{array}$ & $\mathrm{df}$ & Mean Square & $\mathrm{F}$ & Sig. \\
\hline \multirow[t]{3}{*}{1} & Regression & 16.422 & 3 & 5.474 & 5.635 & $.002^{\mathrm{a}}$ \\
\hline & Residual & 48.567 & 50 & .971 & & \\
\hline & Total & 64.989 & 53 & & & \\
\hline
\end{tabular}

a. Predictors: (Constant), NATIONALITY_D, AGE_D, GENDER_D

b. Dependent Variable: ROA

Result of $\mathbf{R}^{2}$ Test. Coefficient of determination $\left(\mathrm{R}^{2)}\right.$ is used to measure the variance of the dependent variable about, its mean that is explained by the independent, or predictor variables. Coefficient determination indicated on how strong the influence of independent variables towards the dependent variables.

Table 5. $\mathrm{R}^{2}$ Test Result

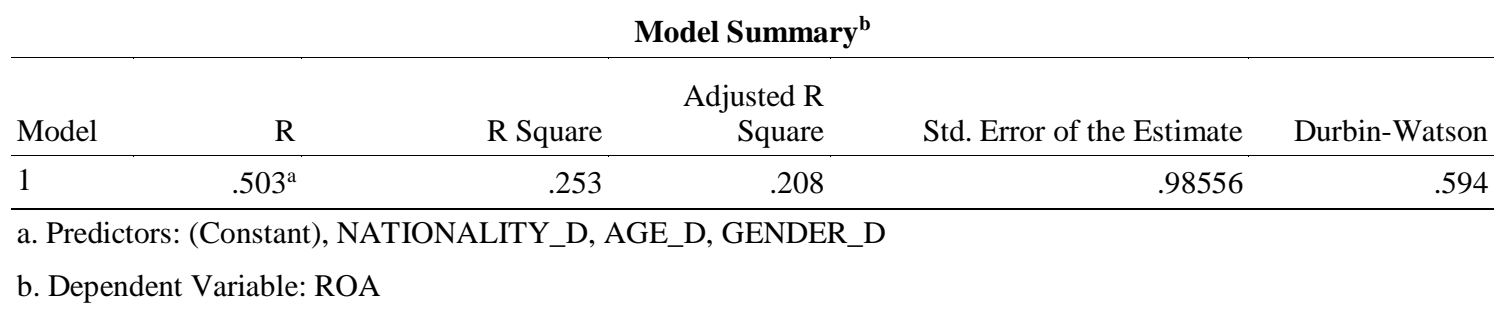

According to table 5, the value of adjusted R Square (Adjusted $\mathrm{R}^{2}$ ) is 0.208 , which means the independent variables affect the dependent variables $20.8 \%$ or the independent variables can explain the dependent variable for $20.8 \%$. The rest $79.2 \%$ is explained by other factors apart from this study.

Result of T-Test. The T-test analyzes the partial relationship between each of independent variable and the dependent variable (Sarwono, 2012). Degree of confidence is $5 \%$. The variable does not statistically have significant impact, if the significant test is 
greater than 0.05 . Otherwise, if the significance is less than 0.05 , then independent have an effect on the dependent variable.

Table 6. T-Test Result

\begin{tabular}{|c|c|c|c|c|c|c|}
\hline \multicolumn{7}{|c|}{ Coefficients $^{a}$} \\
\hline & & \multicolumn{2}{|c|}{ Unstandardized Coefficients } & \multirow{2}{*}{$\begin{array}{c}\text { Standardized } \\
\text { Coefficients } \\
\text { Beta }\end{array}$} & \multirow[b]{2}{*}{$\mathrm{t}$} & \multirow[b]{2}{*}{ Sig. } \\
\hline & Model & $\mathrm{B}$ & Std. Error & & & \\
\hline \multirow[t]{4}{*}{1} & (Constant) & 9.174 & 2.361 & & 3.886 & .000 \\
\hline & AGE & -.667 & .277 & -.299 & -2.407 & .020 \\
\hline & GENDER & -.298 & .408 & -.091 & -.729 & .469 \\
\hline & NATIONALITY & -1.445 & .406 & -.442 & -3.559 & .001 \\
\hline
\end{tabular}

a. Dependent Variable: ROA

\section{FINDINGS AND DISCUSSION}

Age has a significance level less than $0.05(0.02<0.05)$. It means that there is a significant effect of age on financial performance commercial bank in Cikarang. This result conforms to the results obtained by Ararat et al. (2010) who demonstrated that age has a relationship towards financial performance. Young directors can be argued as having more tendencies to be creative, and have higher ability to discover new ideas, innovate quickly, and are less interested in career progression (Cheng et al., 2010; Baker and Mueller, 2002) because perhaps they do not see themselves staying long in the banks. Because of their young age, they will have a tendency to seek other ventures (Cheng, et.al, 2010). The results confirm suggestions that firms with young directors on boards have higher growth than the firm with older director on boards (Hambrick and Mason, 1984).

Nationality has significance level less than $0.05(0.01<0.05)$. It means there is significant effect of nationality on financial performance commercial bank in Cikarang measured by Return on Asset. The significant result has the same result with previous study by Ruigrok and Kaczmarek (2008) and Choi and Hasan (2005). Since internationalization is an emerging phenomenon, and foreign investors in Indonesia have been increasing, appointing foreign board members will be an advantage. This is supported by studies previously done by Oxelheim and Randoy (2003); the appearance of foreign nationals on the team are expected to bring competitive advantages to the firm. As globalization increases the visibility and opportunities for domestic businesses to engage with multinational companies abroad, having foreign directors is also a positive sign of firm internationalization that can attract more foreign investments (Oxelheim and Randoy, 2003).

Gender as a determinant to financial health of commercial banks has been found insignificant in this study (confidence level more tha $0.05(0.469>0.05)$. It means there is no significant effect of Gender on financial performance in commercial bank in Cikarang measured by Return on Asset. As we know, women participation on board is not widely 
regulated in Asia including Indonesia. Compared to other parts of the world, women presence in Asian top executives is still very limited because the social function of women - to be homemakers and caretakers of their homes - means that few women aspire to higher careers and leadership roles. Society dictates that even if they are working, they should be able to juggle the role of mother, wife, and career women. This triple demands often dissuade women to aspire to higher career levels, and thus it is often unexpected that a woman should be on the top board membership. The insignificant result has the same result with previous studies by Adams and Ferreira (2009) and Kusumastuti et al., 2007). Furthermore, there are arguments that women could enlarge the possibility of conflicts (Joshi, et al., 2006; Richard, 2004), slow decision-making (Hambrick, 1996). According to (Jianakoplos and Benasek, 1998) gender lead to differences in responding to risks. These arguments need to be further studied as women are also known for their pastoral, nurturing, and caring roles, as commonly-known for Indonesian women.

There is simultaneously significant effect between age, gender, and nationality on financial performance $(0.02<0.05)$ commercial banks in Cikarang. The significant result has the same result with previous study by Erhardt et al. (2003). Board diversity is favorable based on two reasons (Kang, Cheng, and Gray, 2007). Diversity increases discussion, exchange of ideas and group performance. A diverse board provides different insights and perspectives in facing problem and finding solution. Moreover, the responsibility of every board member is to protect the stakeholders' interest, hence having better representation in terms of age, gender, and nationality can bring about higher competitive advantage for commercial banks and increase their corresponding financial performance.

\section{CONCLUSION}

The study found that board diversity in terms of age and nationality have significant effects on the financial performance of commercial banks, while gender pose no significance as a predictor of firm performance among commercial banks in Cikarang, West Java, Indonesia. This seems to imply that women participation on board is not widely common in Indonesia despite the Indonesian government's vigorous efforts towards gender equality in access to education, business, and in professional life. Over the last decade there has been a tremendous effort to make Indonesian women more empowered citizens and this effort has been shown by the creation of agencies and institutions supporting women's equality, rights, protection, and welfare. Yet compared to other parts of the world, women as top executives is still very limited. Women are demanded to take care of family more than men. In conclusion, insignificant number of women on board is due to the lack of female representation, or lack of competent female leaders. This is an area that needs to be explored further.

There are a number of limitations in this study. Firstly, the sample of this study is relatively small, disallowing generalizations to the entire banking industry in Indonesia. The sample, in Cikarang, should be expanded and more variables should be included. Secondly, this study only includes a few dimensions of diversity. Future studies are 
suggested to accommodate more measure of diversity, for instance diversity in education, tenure, and any other demographic measure of diversity. Thirdly, in addition, this study used cross-sectional analysis in one financial period only. Future studies need to consider the use of longitudinal data to provide more reliable insights to see the effect between board diversity and financial performance.

\section{REFERENCES}

Adams, R.B., Almeida, H., and Ferreira, D. (2009). "Understanding the relationship between founder-CEOs and firm performance". Journal of Empirical Finance, 16 (1), 136-150.

Adams, R.B. and Ferreira, D. (2009). 'Women in the boardroom and their impact on governance and performance". Journal of Financial Economics, 94(2), 291-309

Agrawal, A. and Knoeber, C.R. (1996). "Firm performance and mechanisms to control agency problems between managers and shareholders". Journal of Financial and Quantitative Analysis, 31(3), 377-397.

Ararat, M., Aksu, M., and Cetin, A.T. (2010). Impact of board diversity on boards monitoring intensity and firm performance: Evidence from the Istanbul Stock Exchange, paper presented at the 17th Annual Conference of the Multinational Finance Society, 27-30 June, Barcelona.

Campbell, K. and Minguez-Vera, A. (2008). "Gender diversity in the boardroom and firm financial performance". Journal of Business Ethics, 83(3), 435-451.

Choi, J.J., Park, S.W., and Yoo, S.S. (2007). "The value of outside directors: evidence from corporate governance reform in Korea". Journal of Financial and Quantitative Analysis, 42(4), 941-962.

Choi, S. and Hasan, I. (2005). "Ownership, governance, and bank performance: Korean experience". Financial Markets, Institutions and Instruments, 14(4), 215-242.

Claessens, S., Djankov, S., and Lang, L.H.P. (2000). "The separation of ownership and control in East Asian corporations". Journal of Financial Economics, 58 (1-2), 81112.

Cox, Jr., T. (1991). The multicultural organization. Academy of Management Executive, $5(2), 34-47$.

Darmadi, S. (2013). "Board members' education and firm performance: evidence from a developing economy", International Journal of Commerce and Management, 23 (2), 113-135

Erhardt, N.L., Werbel, J.D., and Shrader, C.B. (2003). "Board of director diversity and firm financial performance". Corporate Governance: An International Review, 11(2), 102-111.

Hambrick, D.C., Cho, T.S., and Chen, M.J. (1996). "The influence of top management team heterogeneity on firms' competitive moves". Administrative Science Quarterly, 41(4), 659-684.

Hambrick, D.C. and Mason, P.A. (1984). "Upper echelons: The organizations as a reflection of its top managers". Academy of Management Review, 9(2), 193-206. 
Haniffa, R. and Cooke, T.E., (2002). "Culture, corporate governance and disclosure in Malaysian corporations". Abacus, 38(3), 317-349.

Haniffa, R. and Hudaib, M. (2006). "Corporate governance structure and performance of Malaysian listed companies". Journal of Business Finance and Accounting, 33(78), 1034-1062.

Herrmann, P. and Datta, D. (2005). "Relationships between top management team characteristics and international diversification: An empirical investigation". British Journal of Management, 16(1), 69-78.

Gianakopulos, N.A. and Bernice, A. (1998). "Are women more risk averse?", Economic Inquiry, 36(4), 620-630.

Kilduff, M., Angelmar, R., and Mehra, A. (2000). "Top management-team diversity and firm performance: Examining the role of cognitions". Organization Science, 11(1), 21-34.

Krishnan, G.P. and Parsons, L.M. (2008). "Going to the bottom line: an exploration of gender and earnings quality", Journal of Business Ethics, 78(1-2), 65-76.

Krishnan, H.A. and Park, D. (2005). "A few good women-on top management teams". Journal of Business Research. 58(12), 1712-1720.

Kusumastuti, S., Supatmi, and Sastra, P. (2007). "Pengaruh board diversity terhadap nilai perusahaan dalam perspektif corporate governance (The impact of board diversity on firm value: Corporate governance perspectives)". Jurnal Akuntansi dan Keuangan (Journal of Accounting and Finance), 9(2), 88-98.

Milliken, F.J. and Martins, L.L. (1996). "Searching for common threads: Understanding the multiple effects of diversity in organizational groups", Academy of Management Review, 21(2), 402-433.

Morck, R., Shleifer, A., and Vishny, R.W. (1989). "Alternative mechanisms for corporate control". American Economic Review, 79(4), 842-852.

Oxelheim, L. and Randøy, T. (2003). "The impact of foreign board membership on firm value". Journal of Banking and Finance, 27(12), 2369-2392.

Reed, R. and Defillippi, R.J. (1990). "Causal ambiguity, barriers to imitation, and sustainable competitive advantage". Academy of Management Review, 15(1), 88102.

Ruigrok, W. and Kaczmarek, S. (2008). Nationality and international experience diversity and firm performance: country effects, working paper, University of St Gallen, St Gallen, September.

Shrader, C.B., Blackburn, V.B., and Iles, P. (1997). "Women in management and firm financial performance: An exploratory study". Journal of Managerial Issues, 9(3), 355-372.

Smith, N., Smith, V., and Verner, M. (2005). Do women in top management affect firm performance? A panel study of 2500 Danish firms, discussion paper. Institute for the Study of Labor, Bonn.

Wireman, M.F., and Bantel, K.A. (1992). "Top management team demography and corporate strategic change". Academy of Management Journal, 35(1), 91-121.

UNDP. (2010). Women's participation in politics and government In Indonesia: A Policy Paper. Jakarta, Indonesia: United Nation's Development Programme. 